\title{
Contested industrial democracy discourses in transnational companies. The case of the ArcelorMittal European Social Dialogue Group
}

\section{Sergio González Begega ${ }^{1}$}

Department of Sociology, University of Oviedo, Spain

\section{Holm-Detlev Köhler. University of Oviedo}

Department of Sociology, University of Oviedo, Spain

\section{Mona Aranea. University of Cardiff}

Cardiff Business School, University of Cardiff, United Kingdom

\begin{abstract}
The article discusses the potential of European transnational company agreements for the development of industrial democracy at European company level. It describes the experience of the ArcelorMittal European Social Dialogue Group, established in 2009 through a European transnational company agreement, as an innovative channel for trade union involvement in corporate decision-making. The conceptual framework draws on a cross-national comparison of industrial democracy discourses in two different European countries, Germany and Spain. A qualitative approach based on structured interviews with trade union representatives and management is used to identify divergent national discourses of employee voice that underlie common misunderstandings of industrial democracy at European level. The findings illustrate the persisting communication challenges trade unions face when engaging in employee representation structures at transnational company level. The article also substantiates that trade union representatives are able to revise and adapt their national discourses on industrial democracy under the influence of European practice.
\end{abstract}

\section{Keywords}

Transnational companies, industrial democracy, European framework agreements, trade unions, company-level social dialogue.

\section{Introduction}

Transnational companies (TNCs) are major employers and highly influential political players in the globalised economy. Industrial democracy remains a major challenge for trade unions in the age of corporate globalization, where there is 'a lack of institutions,

\footnotetext{
${ }^{1}$ Corresponding author:

Sergio González Begega, University of Oviedo, Campus de El Cristo, 33006-Oviedo, Asturias, Spain. Email: gonzalezsergio@uniovi.es
} 
instruments and initiatives allowing employees to pursue transnational strategies matching the globalised approaches of management' (Schömann et al. 2012: 7). Transnational company agreements (TCAs) have gained increasing importance in recent years as promising new tools to establish a labour voice in TNCs (Fichter et al 2011; Dehnen and Pries 2014; Evans 2015). A considerable body of literature has dealt with the potential of TCAs for the implementation of core labour standards at international level and for the transformation of existing institutions of employee representation in TNCs (Telljohan et al 2009; Niforou 2012; Helfen and Sydow 2013). The existing studies on the actual output of TCAs indicate that these tools have a significant potential to improve industrial democracy in TNCs (Egels-Zanden and Hyllman 2007: 219) but more often than not implementation remains far behind trade unions' expectations (Sydow et al. 2014: 491). Research has emphasized the capacity of TCAs to strengthen labour organizing and institutional power at transnational level and to establish trade union cross-border alliances within TNCs (Levesque and Murray 2010; Fairbrother et al. 2013; Williams et al 2015). McCallum (2013: 38) has argued that for trade unions these agreements 'are potentially part of a long-term industrial strategy to build power within a sector or region's largest players'.

Regarding industrial democracy in the European Union, some studies have discussed the role of European trade union federations and European works councils in signing TCAs (da Costa et al 2012; Leonardi 2012; Dehnen 2013). The evolution of European TCAs has to be seen in the general context of the Europeanization of industrial relations and as a product of the political interplay between European management and labour. In this sense, European TCAs constitute an emerging arena of company level social dialogue, in parallel to European works councils (EWCs) or board-level employee representation. However, these studies also emphasise that European TCAs have the potential to enhance industrial democracy and trade union institutional power beyond national and local implementation. The issues of industrial democracy and cross-border trade union cooperation are of an unequivocal global scope, although the challenges become even more pronounced the more national labour forces are covered by a TCA aiming at an increased labour voice in TNCs (Hyman 2016).

The article explores the implementation of the European TCA signed in 2009 by the European Metalworkers Federation (integrated into IndustriAll Europe in 2012) and the European management of ArcelorMittal as a potential tool to enhance industrial democracy and trade union cross-border cooperation in the TNC. ArcelorMittal is the largest steel producer worldwide and a leading industrial employer in Europe. The European structure of ArcelorMittal derives from an ongoing process of corporate concentration and restructuring at transnational level which has reorganized steel industry globally. The literature on European TCAs has mainly concentrated on the automotive and other highly internationalized industries, such as finance or transportation. Less attention has been paid to sectors of delayed internationalization and late transnational corporate concentration. Our analysis thus broadens the lens to other industries and contributes to the existing literature on the practical implementation of European TCAs, industrial democracy and labour organizing at European level (Dehnen and Rampeltshammer 2011; Greer and Hauptmeier 2012; Whittall et al 2017).

The main research question is why the ArcelorMittal European Social Dialogue Group (ArcelorMittal ESDG), established on the basis of the European TCA, has not developed into an effective institution for employee voice at transnational level. The principal argument brought forward is that the functioning of this trade union representative body is influenced by divergent national industrial democracy discourses. The article explores 
motivations and background assumptions underlying labour and management approaches to employee representation at transnational level. The analysis reveals conflicting national-specific understandings and discourses of labour voice by trade unions represented in the ArcelorMittal ESDG. We discuss how different expectations of trade union representatives from Germany and Spain create dissonant cognitions that disrupt industrial democracy at transnational level and whether they can be overcome or not. The country case selection is based on criteria of workforce size and transnational corporate restructuring impact. Contrary to other national operations, corporate restructuring has led to minor changes in production capacity and employment in Germany and Spain. The social dialogue climate between management and employee representatives has not been substantially altered in these countries, thus reinforcing the continuity, progression and influence of their respective industrial democracy discourses at European level. The article explores other non-institutional factors explaining the dysfunction of the ArcelorMittal ESGD (Frege, 2005; Timming and Veersma 2007; Timming 2010).

The following section presents a conceptual framework for the study of collective discourses and understandings of industrial democracy in TNCs. We summarize the main characteristics of the national industrial democracy discourses in Germany and Spain. In succession, we develop a qualitative approach to reveal trade unionists' divergent background assumptions regarding transnational employee voice. In the empirical section we analyse the evolution of the ArcelorMittal ESDG and show how different national perceptions of industrial democracy disrupt employee voice at transnational level. The article concludes with a discussion of the findings. We argue that European TCAs indeed have the potential to enhance industrial democracy in TNCs with operations in the European Union but trade unions need to overcome persisting dissonant cognitions for this potential to unfold.

\section{Transnational labour voice and national industrial democracy discourses}

Industrial relations practitioners and scholars advocating industrial democracy share the basic assumption that the political democracy that exists outside the firm needs to be expanded to the corporate level (IDE Research Group 1981; Adnett and Hardy 2005; Hyman 2016). While there is no universally accepted definition of industrial democracy, all common understandings of the concept involve formal and informal mechanisms that 'facilitate the (direct or indirect) participation of workers in their establishment's decision-making' (IDE Research Group 1981: 4). The notion of industrial democracy thus encompasses a broad array of employee representation practices, including social dialogue. Although based on a pluralism of approaches, these are all concerned with ensuring labour participation and achieving enhanced interest alignment between management and employees through the extension of democratic rules and procedures. The literature has generally focussed on organizational and policy-oriented implications of industrial democracy. Cross-national comparative studies of employee involvement in corporate decision-making tend to be descriptive with limited reflection on sociohistorical aspects and ideological traits that underlie differences in practice. One important exception is Frege's (2005: 172) study on how the historical German and USAmerican 'philosophies on State and society (...) were instrumental in shaping different national responses of how much democracy and in what form was desirable in the industrializing economies'. Her findings emphasize the importance of collective discourse in shaping national industrial relations institutions, including those which refer to employee representation rights and practices (see also Frege and Godard 2010). 
In order to understand the patterns of institutional continuity or change of employee representation at transnational level it is crucial to identify the socio-historical and ideological traits that shape divergent national industrial democracy discourses. Common perceptions at national level blend together or collide in the construction of European employee representation rights and practices. One key challenge in the development of a genuine transnational labour voice is 'how to build common institutions, coordinated practices and attitudes (...) on top of very different national industrial relations traditions' (Köhler and González Begega 2007: 133). Employee representatives from different national backgrounds give different meanings to transnational institutions of employee representation, as has been shown in the research on EWCs. National delegates carry into these bodies a set of nationally constituted expectations with respect to how transnational industrial relations are supposed to unfold. This results in often divergent expectations towards the purpose and practice of employee involvement in corporate decision-making (Whitall et al 2007). These 'dissonant cognitions' (Timming 2010) result in intersubjective noise rather than genuine communication. Dissonant cognitions reinforce competing interest and block transnational identity construction, meaning that employee representatives do not find a common ground on which to build labour internationalism: 'diverse [national] background assumptions lead workers' representatives down divergent and often contradictory paths' (Timming 2010: 530).

The purpose and practice of transnational industrial relations institutions remain contested between management and employees but also between employee representatives from different national origins. A national historical comparison is necessary in order to understand how contrasting industrial democracy discourses create misunderstandings between employee representatives at transnational level. We contrast the distinctive ideational framing of industrial democracy in Germany and Spain. The two countries provide for a balance in terms of company-level industrial relations systems and industrial democracy discourses. A look at the German and Spanish ideational framings of industrial democracy reveals dissonant cognitions regarding the role and functioning of employee participation institutions and practices. The German industrial democracy discourse is rooted in a solid social partnership approach and is institutionally supported by co-determination rights. The adversarial tradition of industrial relations and the absence of well-established forms of participative corporate governance in Spain inhibit the development of a robust co-operative mind-set among employee representatives. Both the institutional framework at home and the perceptions and attitudes towards labour involvement shape the settings and performance of transnational worker participation bodies. Brought together from different national origins, they can mutually adapt and develop into hybrid discourses and practices, overlap in a more or less competitive fashion or collide. The cross-national comparison of industrial democracy discourses in Germany and Spain lays the ground for our theoretically informed case study of the ArcelorMittal ESDG.

\section{Germany. The firm as a matter of public interest}

The German ideational framing of industrial democracy evolved in the context of a latecomer industrialization and political unification during the second half of the $19^{\text {th }}$ Century. Drawing on a Hegelian conception of the state, a group of social reformers around Brentano and Schmoller visualized the capitalist firm as a collective organization rather than a simple private affair. Worker's committees and associations were considered essential to make economic institutions compatible with political democracy and 
guarantee employees' well-being. The idea of an associative economy with intermediary organizations between the citizen and the state, including active worker and craftsmen participation, led the nascent trade union movement to thrive for an institutionalized labour voice in the firm (Frege 2005: 173).

It was not until the Weimar Republic (1919-33) that the socialist trade union and political leaders adopted the very idea of industrial democracy, in which the capitalist firm had to evolve from an employers' autocracy towards a genuine republican factory (Häberle 1978: 136). The ruling social-democratic government introduced codetermination rights at the workplace, regional and national levels. In the early 1920s, trade union theorist Fritz Naphtali (1928) developed a widely discussed industrial democracy concept far beyond the original notion by Sidney and Beatrice Webb (1897), which was limited to collective bargaining. Implementation of industrial democracy in Germany came to a halt as the Nazi Regime (1933-45) marked a rupture of the democratic aspirations at workplace level (Müller-Jentsch 2016).

After 1945, the ideological disputes on industrial democracy developed around the ambiguous and unstable concept of social market economy. Trade unions and left-wing groups heavily opposed the concept and demanded wide-reaching economic and industrial democracy, but were defeated in the dispute over the 1952 Works Constitution Act. The 1951 co-determination law in the coal and steel industry was a noteworthy exception to the restoration of a private capitalist regime in post-war Germany (Hyman 2016: 15).

Industrial democracy re-entered the political agenda in 1970, with the first elected social-democratic government after 1945. The 1976 co-determination law established a quasi-parity representation of shareholders and employees in the supervisory boards of companies with more than 2,000 employees. After the 1970s, a collective learning process among employers and employee representatives has led to a co-operative industrial relations system, in which co-determination and employee participation became part of a renewed concept of social market economy (Köhler 2016). In the German conflict-partnership model, local works councils negotiate workplace issues with the employer and often take a cooperative position as they are legally obliged 'to 'consider the company's economic goals' (Jacobi et al 1998: 191). The rule that a minority of the labour delegates in the supervisory boards of companies are not employees but trade union officials motivates a close coordination between works councils and trade unions and a strong commitment of labour with the long-term profitability of companies. Over time German works council members have become increasingly professionalized, which has also increased the distance between a workforce and its representatives (GumbrellMcCormick and Hyman, 2010: 305).

\section{Spain. Non-participative forms of corporate governance}

Industrialization in Spain remained limited and geographically concentrated in a few areas until the $20^{\text {th }}$ Century, where an ideologically fragmented labour movement started to emerge. The backwardness of Spanish industrialization helps account for early captivation of trade union leaders to revolutionary Marxism, anarchism and syndicalism (Malo Guillén 1982; Cabrera and Del Rey 2007).

The approach of the $19^{\text {th }}$ Century Spanish state towards industrial relations blends together some principles of the social doctrine of the Catholic Church and the influence of German conservative philosopher Karl Krause who was highly critical towards state 
intervention in the economy. Social reformism was aimed at setting the foundations of the social protection system while institutionalizing industrial conflict (Prat and Molina 2014: 209). The objective of political reformers was the incorporation of the emerging working classes into the liberal system, in line with the example of the British labour movement. The attempt to accommodate industrial conflict by endorsing a reformist agenda was at odds with rising social tensions and a revolutionary working class. In a context of expanding industrialization, industrial relations in Spain became characterized by a clearly articulated class antagonism with two main trade unions, the socialistoriented UGT and the anarcho-syndicalist CNT as principal players, and much scepticism towards industrial democracy (Martinez Lucio 1998: 434).

The attempts to introduce consensus and arbitration of industrial conflict through a corporatist institutional framework in the 1920s and early 1930s were discontinued under increasingly difficult economic and political circumstances that led to the Civil War. The Franco Dictatorship (1939-75) marked the end of political democratization and free trade unionism in Spain. The longevity of the Franco Dictatorship explains the absence of an industrial democracy discourse, as previous industrial relations traditions, including the liberal attempts to temper industrial conflict in the early $20^{\text {th }}$ Century, went lost over two generations of political repression.

The new Spanish trade union discourse after 1975 was much inspired by imported ideas from other European countries. The transition to democracy went along with the institutionalization of a dual structure of employee representation in the firm through works councils and trade unions. In Spain, employee delegates perform a double role as trade union officials and employee representatives in local works councils. The two major trade unions, CCOO and UGT, did not invest in developing a robust industrial democracy discourse and took an adversarial perspective towards employers. As a result, nonparticipative forms of corporate governance are the norm and employee representation rights are limited to information and non-binding consultation. The participation in bodies of social dialogue at European level inspired by the co-operative industrial relations model implies a novelty for Spanish employee representatives (Köhler and González Begega, 2007: 143).

\section{Research methods}

The empirical analysis relates the national industrial democracy discourses to the social dialogue practised at transnational level at ArcelorMittal. It explores divergent industrial democracy discourses among German and Spanish employee representatives at the ArcelorMittal European Social Dialogue Group (ESDG). The research design is a Single$\mathrm{N}$ industrial relations case study in a TNC. Single-N studies constitute a well-established research strategy in the literature of company-level European industrial relations and, as indicated by Lervik (2011: 231-232) 'are useful for exploring new phenomena and for exploring, illustrating and developing theory'.

The methodology applied draws heavily on Timming's (2010: 531) ethnomethodological framework for the study of transnational bodies of employee representation. The analysis presented here is not ethnographic in a narrow sense, as the fieldwork was not carried out in the form of direct observation and first-hand data collection. In-company industrial relations are not directly accessible to researchers because of the sensitive nature of the information exchanged there. Data was collected via expert interviews combined with a desk analysis of other written sources such as 
company documents. We applied the ethno-methodological approach selectively to data analysis in order to reveal respondents' divergent background assumptions on industrial democracy and the resulting dissonant cognitions over employee representation and transnational level (Timming 2010: 526).

The fieldwork consisted of fourteen semi-structured interviews conducted between 2013 and 2016 in Germany, Spain, Belgium and Luxembourg. Our data is arguably robust. The sample consisted of ten trade union representatives from Germany and Spain, three officials of the European trade union IndustriALL and one manager from the company's European Human Resources (HR) Department. This includes all former or current members of the ArcelorMittal ESDG in representation of the German and Spanish workforce. The fieldwork was complemented by an exhaustive analysis of trade union and company-related secondary sources.

The country case selection is based on criteria of workforce size and crisis impact. The two countries selected, Germany and Spain, each account for a comparably large portion of the company's European workforce - between 4,000 and 10,000 employees each. Germany and Spain constitute comparably regular cases. They were only marginally affected by crisis-related restructuring and workforce reductions after 2009, in contrast to other large national operations in Western Europe such as Belgium and France. These two countries are excluded from the analysis as they constitute outlier cases of social dialogue in ArcelorMittal, with forced lay-offs and major plant closures. This has strongly deteriorated the social dialogue climate between management and labour. Faced with the impact of corporate restructuring, employee representation in both countries retrenched to the local level, thus causing a rupture in the continuity, progression and European influence of their industrial democracy discourses.

\section{German and Spanish industrial democracy discourses at the ArcelorMittal ESDG}

\section{High hopes go down. Establishing European social dialogue in ArcelorMittal}

The European metalworking sector has always attracted the interest of practitioners and scholars in the fields of transnational trade union cooperation and employee involvement in corporate decision making. With production sites in close to twenty countries, ArcelorMittal is standing out as a global player in this industry. The company was established in 2006 after the takeover of the European consortium Arcelor by the AngloIndian corporation Mittal Steel. The reduction in global steel demand since 2008 has led to the restructuring of several production facilities in Europe. ArcelorMittal has concentrated production in the most profitable sites while closing a number of low profit plants. This has strained industrial relations in some national operations, namely Belgium and France. Also, increasing inter-plant competition in the context of a broad restructuring plan has negatively affected transnational coordination of labour voice by European trade unions.

In 2009, after the announcement of major restructuring plans affecting European facilities, the corporate management of ArcelorMittal and the European Metalworkers Federation (EMF, integrated into IndustriALL Europe in 2012) reached an European TCA aimed 'at promoting social dialogue at national and local level' (EMF 2009). The ArcelorMittal European TCA was met with much enthusiasm in the respective literature as an example of 'best practice in times of crisis' (Teissier 2013: 74), given the rapid and 
effective dialogue process that had led to the agreement (see also Rüb et al 2013: 173). For the purpose of transnational social dialogue between management and trade union representatives, the TCA established the ArcelorMittal ESDG as a new labour representation body, along with the already existing EWC. The mission of the ArcelorMittal ESDG was to ensure a 'permanent exchange [between national and European trade union representatives and corporate management] at high level' (EMF 2009: 4-5). The new trade union delegation was to work in close liaison with other bodies for employee representation in the company, most important among them the EWC. Ten European national workforces are represented by one ESDG delegate each. Three EMF (IndustriALL) trade union officials also attend the meetings. The management side is represented by a flexible number of corporate managers (between three and 13) depending on the topics under discussion. A representative of the European HR Department always attends ESDG meetings.

The ArcelorMittal ESDG met on a regular basis over a period of two years. The impact of the restructuring plans soon disrupted its functioning. From 2010 onwards, local labour unrest in Belgium and France very much blocked any attempts for transnational conflict resolution in the ESDG. The European TCA included a clause which committed the signatories to avoid the closures of facilities and job losses in European facilities (EMF 2009: 2). The general idea was to distribute production between plants and ensure that all production sites survive. In a clear departure from the spirit of the European TCA, management 'changed its strategy and fostered a concentration [of production] on the socalled core plants' (Breidbach et al 2013: 312). The closures of mothballed blast furnaces in Liège and Florange were considered to be violations of the European TCA by Belgian and French trade unions, as they included forced lay-offs. Concerning the former commitment to an equal distribution of demand, corporate management argues that:

"To organize production in this way was not the best way for the company ... So we needed to change it."

Interview quotation. ArcelorMittal HR Manager, 2015.

In the absence of further progress in European social dialogue, management decided to put the ESDG on hold in 2012. IndustriALL representatives admit that the atmosphere was very much poisoned by the situation in Belgium and France. The main stumbling blocks for European social dialogue were the local consequences of the aggressive restructuring plan launched by the company. The decision to discontinue ESDG meetings illustrates the fragility of employee representation structures at transnational level in case of implementation of major restructuring programmes and increased inter-plant competition.

\footnotetext{
"We had to put [the ESDG] on hold because the situation was too confrontational ... The ESDG was not bad but it never lived up to the expectations ... Management is just paying lip service to social dialogue ... without actually being prepared to play that role [of a social partner]."

Interview quotation. ESDG coordinator. IndustriALL, 2014.

"It became rougher, the words became harsher (...), French and Belgian managers and delegates entered into extreme problems of communication during the crisis."
}

Interview quotation. German ESDG member. IGMetall, 2014.

Even though the corporate decision was taken in agreement with IndustriALL, the withdrawal of European social dialogue was felt as a disadvantage for labour because access to corporate management became more difficult. Since the takeover of Arcelor in 2006 the autonomy of the company's European HR Department has been gradually reduced. According to labour representatives in the ESDG, HR managers are comparably 
less experienced and have less authority than those who negotiated the European TCA in 2009. The increased centralization of corporate decision-making with the corporate board of directors has resulted in a retreat from social dialogue. The strict voluntaristic nature of the European TCA meant that trade union officials could not exert actual pressure on management to re-install the ESDG.

"We're all aware that this [the ESDG] is a part of the agreement ... but we cannot enforce it."

Interview quotation. German ESDG member. IGMetall, 2014.

"Now there exists less interest in social dialogue from the part of the ArcelorMittal corporate management than before ... That is a fact."

Interview quotation. Spanish ESDG member. UGT, 2014.

Corporate management and IndustriALL tentatively re-started the ESDG in November 2014, once negotiations in Belgium and France were completed and local conflict was largely settled. The first ESDG meeting after the two-year break concluded in a joint commitment to proceed with social dialogue at European level despite the many conflicts and controversial interpretations of the European TCA. Trade union delegates are also keen to revitalize the ESDG as an important add-on to local, national and other European structures of employee representation, such as the EWC. Management also considers the ESDG as a useful structure for social dialogue.

"We know that we have to bring back to life the ESDG ... We have other means to get to the corporate management of ArcelorMittal ... But this is a very important body for employee representation and trade unions ... It's a trade union body ... It gives us access to central management through another way."

Interview quotation. Spanish ESDG member. CCOO, 2016.

"We have to really discuss at the ESDG and never interrupt the process ... No matter the difficulties ... We need to sit at the same table, management and trade union representatives."

Interview quotation. ArcelorMittal HR Manager, Luxembourg, 2015.

\section{Contradicting industrial democracy discourses? The views of German and Spanish ESDG members}

The German and Spanish national workforces in ArcelorMittal were not severely affected by crisis-related restructuring after 2009. The Spanish workforce suffered strong reductions in 2007-14 (around 25\% of the total workforce) but those were carried out through early retirement schemes and other individual compensatory payments. Contrary to Belgium and France, social dialogue between management and trade unions remained active and national industrial democracy discourses were not dominated by the impact of corporate restructuring plans. This allows us to examine the impact of two different but stable national industrial democracy discourses on the functioning of the ArcelorMittal ESGD.

The ArcelorMittal ESDG was established following inspiration by a dual system of employee representation. For IndustriALL, the aim was to create a trade union structure at transnational level that functioned alongside and in cooperation with the existing EWC. The initial plan was for all delegates in the ArcelorMittal ESDG to be trade union officials with no company ties so that labour cooperation could be fostered and inter-plant competition would not block social dialogue.

"What we wanted to create (...) was a European trade union delegation body at transnational level and in parallel to the EWC (...) The idea was that all thirteen labour delegates would be outsiders. But we 
did in the end not manage to have that (...). If you look at other representation models, very often the employee representatives are accompanied by an external trade union officer. And that was lacking."

Interview quotation. ESDG coordinator. IndustriALL, 2014.

This posed no problem for German delegates, as the structure of the ArcelorMittal ESDG largely replicated that of their national bodies for employee representation. They were IGMetall trade union officials not employed by ArcelorMittal. The consensual rationale behind the planned functioning of the ArcelorMittal ESDG was also very familiar for German representatives. The European TCA was based on a consensual industrial relations logic. Trade unions in Germany are used to responsibly co-operating with management for the long-term profitability of companies.

"For us, it makes complete sense ... We decided that the EWC should be responsible for the negotiation of international problems and the ESDG, at the higher, political level of social dialogue and action is where IndustriALL should operate."

Interview quotation. German ESDG member. IGMetall, 2013.

"The EWC is for employee representatives meanwhile the ESDG is for trade union officials ... Members of local and national works councils should not be part of this body. The ESDG is devoted to social dialogue between trade unions and corporate management representatives ... And social dialogue at the higher level should not be affected by local problems and quarrels ... This is a very important distinction for us."

Interview quotation. German ESDG member. IGMetall, 2015.

In the case of the Spanish delegation the situation was somewhat different. Spanish delegates fulfil a double-role as trade union officials and employee representatives in local works councils. As only one seat is allocated to each national delegation, the Spanish national representative is an UGT trade union official and employee of ArcerlorMittal. The other major trade union among the Spanish workforce, CCOO, is represented by the IndustriALL coordinator, who is a member of CCOO and participates in all ArcelorMittal ESDG meetings. He is likewise both trade union official and employed by ArcelorMittal Spain. Contrary to the German delegates, the Spanish representatives look with suspicion towards trade union officials from other national delegations who are not ArcelorMittal employees and thus lack insider knowledge. The adversarial background of Spanish industrial relations tradition also plays a relevant role here. The absence of a robust industrial democracy discourse in Spain affects the view and understanding of labourmanagement relations at the transnational level.

"Certainly, for the management it is easier to speak to an employee representative who is not part of the
workforce that is true. But I am one of those who think that for workers, the opposite is also true. Your
actual interest [as employee representative] is to be able to transfer the real needs and interest of the
company's workers ... When we go to European bodies we have to defend our workforce ... We are
representatives of all the employees in Spain, albeit coming from different trade unions." Interview quotation. Spanish ESDG member. UGT, 2014.

"In Germany there exists a co-determination system ... but we don't have these possibilities here ... We don't have them back in Spain because our cultures are different and we don't have it here, at the transnational level ... No matter what the agreement [European TCA] says."

Interview quotation. Spanish ESDG member. UGT, 2014.

A closer look at the German and Spanish delegates' perceptions reveals a problem of dissonant cognitions on the role and functioning of the ArcelorMittal ESDG. Although the failing enthusiasm of the management after 2010 reduced the manoeuvring space for the labour side, another core problem of employee representation through the ArcelorMittal ESDG concerns labour's lack of strategical unity and understanding of industrial democracy at the transnational level. Spanish delegates take a more adversarial 
stand to the ESDG while in the case of German delegates the meetings are approached with a more co-operative mind-set. German delegates identify the adversarial approach to industrial relations by Belgian and French delegates (though not particularly Spanish) as one key stumbling block for the functioning of social dialogue at European level. As for the Spanish delegates, they partly uphold the adversarial industrial relations tradition pinpointed for Belgian and French delegates but also see the merit of the German social partnership approach. The absence of relevant industrial conflict at the local level has helped them to adopt a more open approach towards industrial relations at the European level. The Spanish delegates are aware of this. They acknowledge that the participation in bodies of social dialogue at European level inspired by a more co-operative industrial relations model implies a novelty for them but also a potential learning experience. Participation in transnational bodies of employee representation (i.e. the ArcelorMittal ESDG but also the EWC) has given Spanish delegates the opportunity to question established background assumptions and practices on industrial democracy and to develop a more pro-active and open discourse towards company-level social dialogue.

\footnotetext{
"Certainly, the interest in social dialogue has been reduced from the management side ... But I believe, there should be more pressure on our side. The problem is that there is too little power, too little energy ... too little mutual understanding ... It cannot be that we neglect the European level like that."

Interview quotation. German ESDG member. IGMetall, 2013.

"The German perspective often has much logic for me, today even more than before ... It is alien to me, of course ... But I need to be smart enough to defend the interest of the Spanish workforce ... and preserve the presence and investments in my plants. This is a task I did not have before at the local level ... Because of that I have to be flexible and learn to act differently because it is a different [European] level."

Interview quotation. Spanish ESDG member. UGT, 2015.
}

\section{Conclusion}

The implementation process of the ArcelorMittal European TCA provides for an insightful case study of labour's attempt to build up industrial democracy at transnational level. The European TCA established an innovative trade union body of European industrial relations. The ArcelorMittal ESGD institutionalized a dual channel employee representation structure at company level along with the already existing EWC. The assessment of the actual practice of the ArcelorMittal ESGD is mixed. The arrangements laid down in the European TCA have not developed their full potential. The slow process of social dialogue can partly be explained by a reduced interest from corporate management. The findings show that management is less interested in conflict resolution at transnational level compared to the time when the European TCA was signed. Also, labour unrest reached unprecedented levels since 2010, due to the overall reduction of production capacity with a particular impact on Belgian and French locations. The company has violated important parts of the European TCA concerning trade union participation, including the commitment to install national social dialogue groups. The implementation of other aspects such as training guidelines for trade union representatives is also being delayed. As shown in the section, trade union delegates see the voluntaristic nature of the underlying European TCA as a decisive weakness for the ArcelorMittal ESDG.

The shortcomings of European social dialogue in ArcelorMittal cannot be explained one-dimensionally by management-related obstacles. The little manoeuvring space left to labour delegates has not been put to use effectively to build up institutional power in the 
TNC. The purpose, composition and rules of the ArcelorMittal ESDG remain contested between labour delegates due to different national discourses of industrial democracy. Delegates from Germany are company outsiders according to national structures of employee representation. They hold that high level trade union officials are best prepared to shape labour voice at transnational level. This is in line with the overall IndustriALL approach. Spanish delegates, on the other hand, insist that labour delegates should hold a double role as trade union officials and employee representatives. Their narrative rejects company outsiders as uninformed and thus weak employee representatives.

A second source of dissonant cognitions is the overall standpoint that the ArcelorMittal ESDG should take towards corporate management. German delegates extent the national cooperative tradition of co-determination to the transnational level. They are willing to engage with company policy as responsible co-managers and are regularly taken aback by the conflictive approached followed by other national delegates. Spanish delegates follow an adversarial industrial relations approach but the participation in European structures of labour representation seems to have triggered a transformation in their industrial democracy discourse. Neither Germany nor Spain have been severely affected by the crisis-related restructuring set in place by the TNC. The two national industrial democracy discourses are now to some extend moving closer together. The case study shows that dissonant cognitions of industrial democracy still persist but such contrasting institutional background have in part begun to blend together. As the findings presented here show, the national background of labour representatives involved in transnational social dialogue structures can indeed pose sizeable challenges to trade union co-operation. Dissonant cognitions on industrial democracy are important but labour representatives have manoeuvring space in the ways they transfer national discourses to the transnational level. The diversity of institutional backgrounds among labour delegates does not always have an over-determining negative effect on the functioning of labour representation bodies. This is exemplified by Spanish delegates at the ArcelorMittal ESDG, who have been able to revise their industrial democracy discourse under the influence of European practice.

The ArcelorMittal ESDG was established against the background of a divided European workforce that has been largely unable to build up European solidarity. The case of ArcelorMittal ESDG illustrates a persisting challenge for employee representation in TNCs: corporate restructuring affects the understandings and practice of employee representation and stimulates disagreement among labour delegates. The institutional legacy of national trade unions has a more or less pronounced effect depending on the impact of corporate restructuring. The dysfunction of the ArcelorMittal ESDG can thus be attributed to the differing national perspectives on industrial democracy but also to the effects of corporate restructuring and increased inter-plant competition after 2010. Contrary to other cases in the literature, particularly in the automotive sector (i.e. General Motors and Volkswagen), the ArcelorMittal ESDG has not strengthened the performance of existing bodies for employee representation such as the EWC or to intensify social dialogue at European level. The failure of the ArcelorMittal ESDG to define a mobilizing project for the European workforce shall not however overshadow the fact that there is considerable common ground to walk on for labour in the TNC. The conclusions of the case study presented here are largely unique to ArcelorMittal but can nevertheless inform other studies on transnational industrial democracy. Tracing strategic disagreements back to the institutional legacies of labour might serve as a first step to developing an effective voice in TNCs. 


\section{References}

Adnett N and Hardy S (2005) The European social model. Cheltenham: Edward Elgar.

Breidbach M, Hering K and Kruse W (2013) Globale Unternehmen. Lokale Interessenvertretung. Hamburg: VSA.

Cabrera M and del Rey F (2007), The Power of Entrepreneurs: Politics and Economy in Contemporary Spain. New York: Berghan Books.

da Costa I, Pulignano V, Rehfeldt U and Telljohann V (2012) Transnational negotiations and the Europeanization of industrial relations. Potential and obstacles. European Journal of Industrial Relations 18(2): 123-137.

Dehnen V and Rampeltshammer L (2011) Transnationale Solidarität auf betrieblicher Ebene: Utopie oder Realität. Der EBR bein General Motors. In: Gerlach F, Greven T, Mückenberger U and Schmidt E (eds.) Solidarität über Grenzen: Gewerkschaften vor neuer Standortkonkurrenz. Berlin: Stigma, pp. 109-130.

Dehnen V (2013) Transnational alliances for negotiating international framework agreements. Power relations and bargaining processes between global union federations and European works councils. British Journal of Industrial Relations 51(3): 577-600.

Dehnen V and Pries L (2014) International framework agreements: a thread in the web of transnational labour regulation. European Journal of Industrial Relations 20(4): 335350 .

Egels-Zanden M and Hyllman P (2007) Evaluating strategies for negotiating workers' rights in transnational corporations: the effects of codes of conduct and global agreements on workplace democracy. Journal of Business Ethics 76(2): 207-223.

European Metalworkers Federation (EMF) (2009) Managing and Anticipating Change at ArcelorMittal. Brussels: EMF.

Evans P (2015) National labor movement and transnational connexions. Global labor's evolving architecture under Neo-Liberalism. Global Labor Journal 5(3): 258-282.

Fairbrother P, Hennebert MA and Lévesque C (2013) Transnational trade unionism. Building union power. New York: Routledge.

Fichter M, Helfen M and Schiederig K (2011) Kann transnationale Solidarität auf Konzernebene organisiert werden? Der Ansatz der internationalen Rahmenabkommen. In: Gerlach F, Greven T, Mückenberger U and Schmidt E (eds.), Solidarität über Grenzen. Gewerkschaften vor neuer Standortkonkurrenz. Berlin: Sigma, pp. 75-94.

Frege C (2005) The discourse of industrial democracy: Germany and the US revisited. Economic and Industrial Democracy 26(1): 151-175.

Frege C and Godard J (2010) Cross-national variation in representation rights and governance at work. In: Wilkinson A, Gollan P, Marchington M and Lewin D (eds.) The Oxford Handbook of Participation in Organizations. Oxford: Oxford University Press, pp. 526-551.

Greer I and Hauptmeier M (2012) Identity work. Sustaining transnational collective action at General Motors Europe. Industrial Relations 51(2): 275-299.

Gumbrell-McCormick R and Hyman R (2010) Works Councils. The European model of industrial democracy? In: Wilkinson A, Gollan P, Marchington M and Lewin D (eds.) 
The Oxford Handbook of Participation in Organizations. Oxford: Oxford University Press, pp. 286-314.

Häberle EJ (1978) Zum Mitbestimmungsgesetz von 1976. In Huber J and Kosta J (eds.) Wirtschaftsdemokratie in der Diskussion. Köln/Frankfurt a.M.: EVA, pp. 119-138.

Helfen M and Fichter M (2013) Building Transnational Union Networks across global production networks: conceptualising a new arena of labour-management relations. British Journal of Industrial Relations 51 (3): 553-576.

Helfen M and Sydow J (2013) Negotiating as institutional work. The case of labour standards and international framework agreements. Organization Studies 34(8): 10731098.

Hyman R (2016) The very idea of democracy at work. Transfer 22(1): 11-24.

IDE Research Group (1981) Industrial democracy in Europe. Oxford: Clarendon Press.

Jacobi O, Keller B, Müller-Jentsch W (1998) Germany: Facing new challenges. In: Ferner A and Hyman R (eds.) Changing Industrial Relations in Europe. Oxford: Blackwell, pp. 190-238.

Köhler HD (2016) Reconstruction and restoration: the legacies of post-war German Industrial Sociology. Work, Employment and Society 30(6): 1017-1029.

Köhler HD and González Begega S (2007) Still learning from Europe. Spanish participation in European Works Councils. In: Whittall M, Knudsen H and Huijgen F (eds.) Towards a European labour identity? The case of the European Works Council. London: Routledge, pp. 132-149.

Leonardi S (ed.) (2012) European Action on Transnational Company Agreements. A stepping stone towards real international industrial relations? Rome: Instituto di Ricerche Economiche e Sociali - IRES.

Lervik JEB (2011) The single MNC as a research site. In: Piekkari R and Welch C (eds) Rethinking the case study in international business and management research. Cheltenham: Edward Elgar, pp. 229-250.

Lévesque C and Murray G (2010) Trade union cross-border alliances within MNCs: disentangling union dynamics at the local, national and international levels. Journal of Industrial Relations 41(4): 312-332.

Malo Guillén JL (2005) El Krausismo Económico Español. Estudio Introductorio. Madrid: Fundación ICO.

Martínez Lucio M (1998) Spain. Constructing institutions and actors in a context of change. In: Ferner A and Hyman R (eds.) Changing Industrial Relations in Europe. Oxford: Blackwell, pp. 426-458.

McCallum JK (2013) Global unions, local power. The new spirit of transnational labor organizing. Ithaca: Cornell University Press.

Müller-Jentsch W (2016) Formation, development and current state of industrial democracy in Germany. Transfer 22(1): 45-62.

Naphtali F (1928) [1977] Wirtschaftsdemokratie. Köln/Frankfurt a.M.: EVA.

Niforou C (2012) International framework agreements and industrial relations governance: Global rhetoric versus local realities. British Journal of Industrial Relations 50(2): 352-373. 
Prat M and Molina O (2014) State corporatism and democratic industrial relations in Spain 1925-1935. A reappraisal. Labor History 55(2): 208-227.

Rüb S, Platzer HW and Müller T (2013) Transnational Company Bargaining and the Europeanization of Industrial Relations. Prospects for a Negotiated Order. Oxford: Peter Lang.

Schömann I, Jagodzinski R, Boni G, Clauwaert S, Glassner V and Jaspers T (2012): Transnational collective bargaining at company level. Brussels: ETUI.

Sydow J, Fichter M, Helfen M, Sayim KZ and Stevis D (2014) Implementation of Global Framework Agreements: towards a multi-organizational practice perspective. Transfer 20(4): 289-504.

Teissier C (2013) Dealing with restructuring through a transnational company agreement? In: Leonardi S (ed.) European action on Transnational Company Agreements. A stepping stone towards real international industrial relations? Rome: IRES: pp. 74-89.

Telljohann V, Da Costa I, Müller T, Rehfeldt U and Zimmer R (2009) European and international framework agreements: new tools of transnational industrial relations. Transfer 15(3-4): 505-525.

Timming A (2010) Dissonant cognitions in European works councils: A 'comparative ethnomethodological' approach. Economic and Industrial Democracy 31(4): 521-535.

Timming A and Veersma U (2007) Living apart together? A chorus of multiple identities. In: Whittall M, Knudsen H and Huijgen F (eds.) Towards a European labour identity? The case of the European Works Council. London: Routledge, pp 41-54.

Whittall M, Knudsen H and Huijgen F (eds.) (2007) Towards a European labour identity? The case of the European Works Council. London: Routledge.

Whittall M, Lucio MM, Mustchin S, Telljohann V and Sánchez FR (2017) Workplace trade union engagement with European Works Councils and transnational agreements: The case of Volkswagen Europe. European Journal of Industrial Relations 23(4): 397414.

Williams G, Davies S and Chinguno C (2015) Subcontracting and labour standards: Reassessing the potential of international framework agreements. British Journal of Industrial Relations 53(2): 181-2013.

\section{Acknowledgements}

The research was supported by the Changing Employment Project. Marie Curie ActionsNetworks for Initial Training (ITN). Reference number FP7-PEOPLE-2012-ITN-317321. The authors are members of the PROMEBI (Promoting Employment and Welfare in Europe) Research Group at the University of Oviedo (Ref. FC15-GRUPIN14-086). 